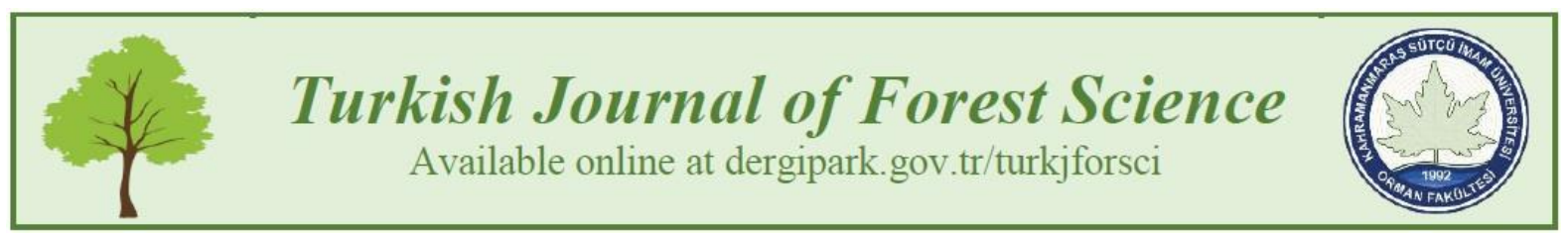

\title{
ASSESSMENT OF BIOCLIMATIC COMFORT ZONES USING THE RAYMAN MODEL: A CASE STUDY OF SULAIMANI - IRAQ
}

\author{
Shakhawan HAMA SHAREF ${ }^{1}$, Hakan OGUZ ${ }^{2, *}$ \\ ${ }^{1}$ Department of Soil Science and Plant Nutrition, Harran University, Sanliurfa \\ ${ }^{2}$ Department of Landscape Architecture, Kahramanmaras Sutcu Imam University, Kahramanmaras \\ *Corresponding author: hakan@ksu.edu.tr
}

Shakhawan HAMA SHAREF: https://orcid.org/0000-0002-2726-5055

Hakan OGUZ: https://orcid.org/0000-0002-0855-2032

Please cite this article as: Hama Sharef, S. \& Oguz, H. (2020) Assessment of bioclimatic comfort zones the Rayman model: A case study of Sulaimani - Iraq. Turkish Journal of Forest Science, 4(2), 408-423.

\section{ESER BILGISI / ARTICLE INFO}

Araștırma Makalesi / Research Article

Geliş 2 Eylül 2020 / Received 2 September 2020

Düzeltmelerin gelişi 17 Eylül 2020 / Received in revised form 17 September 2020

Kabul 17 Eylül 2020 / Accepted 17 September 2020

Yayımlanma 24 Ekim 2020 / Published online 24 October 2020

\begin{abstract}
This study is conducted to retrieve bioclimatic comfort zones for outdoor recreation planning in Sulaimani province, Iraq. Spatial distribution of Physiological Equivalent Temperature (PET), which is a measure of bioclimatic comfort, was retrieved for the city of Sulaimani using meteorological data. The air temperature, relative humidity and wind speed data were employed for the calculation of PET. Data recorded at 15:00 obtained from 7 meteorological stations over the period from 1992-2015 were used to calculate monthly PET with the Rayman model. PET was spatially interpolated using IDW tool in ArcGIS 10.2 to convert point-data consisting of PET for each individual meteorological station into a continuous surface. Therefore, spatial distribution maps of PET for outdoor recreation activities were created after analyzing the maps. The results revealed that the lowest PET determined was around $4.8^{\circ} \mathrm{C}$ in Penjwin area during January while the highest PET determined as $59.6^{\circ} \mathrm{C}$ in northeast of Sulaimani, Halabja during July. On the other hand, the results also revealed that Sulaimani city, Dukan and Penjwin areas are founded to be more suitable for tourism especially during summer months compared to others within Sulaimani Province. The final results of this study may be used by recreation authorities in Sulaimani in the near future.
\end{abstract}

Keywords: Bioclimatic conditions, GIS, meteorological data, PET.

\section{RAYMAN MODELII İLE BIYYOKLIMATIKK KONFOR ZONLARININ BELIRLENMESİ: SÜLEYMANIYE-IRAK ÖRNEĞI}

ÖZET: Bu çalışma, Irak'ın Süleymaniye şehrinin açık hava rekreasyon planlaması için biyoklimatik konfor bölgelerini elde etmek amacıyla yapılmıştır. Meteorolojik veriler kullanılarak biyoklimatik konforun bir ölçüsü olan Fizyolojik Eşdeğer Sicaklığının (PET) mekansal dağılımı Süleymaniye şehri için elde edilmiştir. PET'in hesaplanmasında hava 
sıcaklığı, bağıl nem ve rüzgar hızı verileri kullanılmıştır. 1992-2015 yılları arasında 7 meteoroloji istasyonundan saat 15:00'de kaydedilen veriler, Rayman modeli ile aylık PET hesaplamasında kullanılmıştır. PET, her bir meteoroloji istasyonu için PET'ten oluşan nokta verilerini sürekli bir yüzeye dönüştürmek için ArcGIS 10.2'deki IDW aracı kullanılarak mekansal enterpolasyona tabi tutulmuştur. Bu nedenle, bu haritalar analiz edildikten sonra açık hava rekreasyon etkinlikleri için PET'in mekansal dağılım haritaları oluşturulmuştur. Sonuçlar, tespit edilen en düşük PET'in Ocak ayında Penjwin bölgesinde $4,8{ }^{\circ} \mathrm{C}$ civarında olduğunu, Temmuz ayında Halepçe, Süleymaniye'nin kuzeydoğusundaki en yüksek PET'in $59,6{ }^{\circ} \mathrm{C}$ olduğunu ortaya koymaktadır. Öte yandan sonuçlar Süleymaniye, Dukan ve Penjwin bölgesinin özellikle yaz aylarında turizme daha uygun olduğunu ortaya koymuştur.

Anahtar kelimeler: Biyoklimatik koşullar, CBS, meteorolojik veriler, PET.

\section{INTRODUCTION}

Climate and atmosphere influence humans' well-being and prosperity. This study incorporates the meteorological parameters of air temperature, relative humidity, and wind speed, which influence human being thermo-physiologically in indoor and outdoor.

Until now several indices have been developed over the last decades and used in many studies to retrieve the thermal conditions of outdoor activities (Mieczkowski, 1985; Hoppe, 1999; Matzarakis, et al., 1999; Morgan et al.. 2000; Toy et al., 2005; Matzarakis, 2006; Matzarakis et al., 2007; Matzarakis et al., 2010; Zengin et al., 2010; Lin and Matzarakis, 2011; Farajzadeh and Matzarakis, 2012; Daneshvar et al., 2013; Topay, 2013; Yilmaz et al., 2013; Matallah et al., 2020; Hamad and Oguz, 2020). Most widely used indices for thermal comfort analysis are Predicted Mean Vote (PMV), Physiologically Equivalent Temperature (PET), Standard Effective Temperature (SET) and Perceived Temperature (PT) (Matzarakis, 2006). The most popular indice in thermal comfort analysis is the PET developed by Matzarakis et al., (2007 and 2010), which requires at least three meteorological parameters of air temperature, relative humidiy and wind speed. The advantage of PET indice compared to other thermal indices is that PET uses the advantage of a widely known temperature unit $\left({ }^{\circ} \mathrm{C}\right)$, which makes results easily understandable (Matzarakis et al., 1999; Daneshvar et al., 2013).

Outdoor bioclimatic comfort is influenced by the microclimatic conditions, particularly air temperature, relative humidity, wind speed and radiation fluxes, by a set of personal parameters, such as physical activity, type of cloth and age, and also by psychological factors, namely motivation, individual preferences and cultural aspect. (Nikolopoulou and Steemers, 2003; Stathopoulos et al. 2004; Knes and Thorsson, 2006).

Unfortunately, data on several of these parameters, such as short and long wave radiation, are generally not available in meteorological records. As a result, climate assessments and thermal comfort studies have often resorted to the use of climate indices without these key factors. For example, IPCC (2001), describes the effect of weather and climate on humans with a simple index based on a combination of air temperature and relative humidity. The exclusion of important meteorological data (wind speed and radiation fluxes) and thermo-physiological (activity of humans and clothing) variables seriously diminishes the significance of the results. 
The main objectives of this study are to:

- Calculate PET values through Rayman Model.

- Create a map for Sulaimani City, Iraq using GIS.

- Determine the thermal comfort zones for outdoor recreating planning in Sulaimani City, Iraq.

- Provide information to recreation planners in Sulaimani City to retrieve the optimal months suitable for visitors.

\section{MATERIALS AND METHODS}

\section{Study Area}

Sulaimani city is located in the northern part of Iraq. It is situated between latitudes $\left(35^{\circ} 37^{\prime}\right.$ $\left.36^{\prime \prime}, 35^{\circ} 28^{\prime} 08^{\prime \prime} \mathrm{N}\right)$ and Longitudes ( $\left.45^{\circ} 17^{\prime} 57^{\prime \prime}, 45^{\circ} 29^{\prime} 56^{\prime \prime} \mathrm{E}\right)$. It shares border with Iran to the northeast, Erbil to the west and Kirkuk Governorate to the south as illustrated in Figure 1. Sulaimani governorate has an area of $11789 \mathrm{~km}^{2}$.

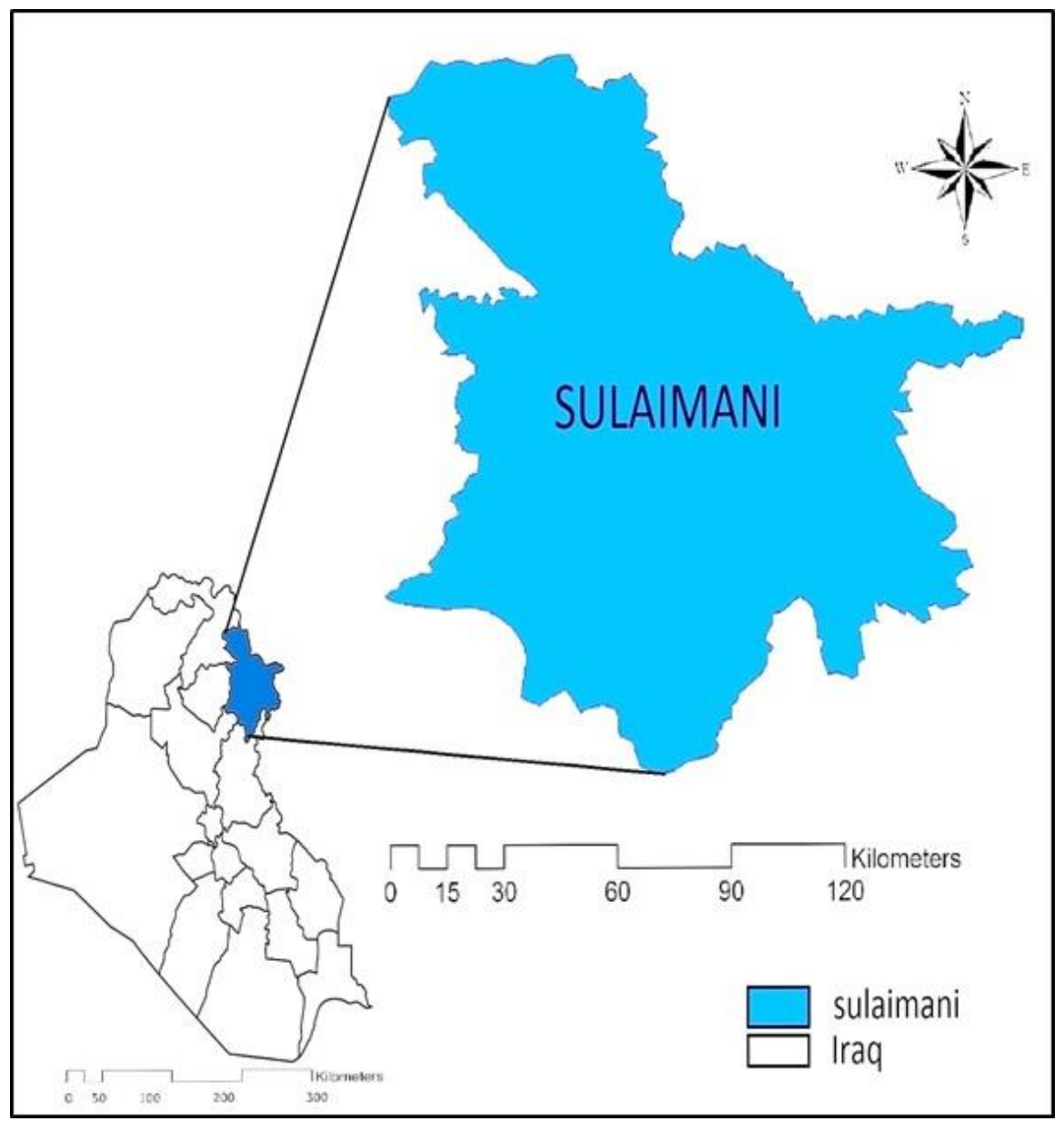

Figure 1. Location map of the study area.

The study area is characterized by a Mediterranean climate. According to Koppen classification it is classified as type CSA, which is characterized by warm and dry summer, wet and cold winter. There are two short seasons (spring and autumn) between winter and summer with 
moderate climate conditions and a maximum temperature $23^{\circ} \mathrm{C}$. Summer lasts from the beginning of May to the beginning of October and winter extends from November until the start of March. In winter, especially in January, the temperature decreases to $5^{\circ} \mathrm{C}$ or even less than $-1^{\circ} \mathrm{C}$. The highest temperatures, ranging between from $45^{\circ} \mathrm{C}$ to $48^{\circ} \mathrm{C}$, are usually recorded between June and September. Much of the precipitation occurs from November until April. Generally, the annual precipitation of Sulaimani city is $(648 \mathrm{~mm})$. However, this has decreased in recent times due to climatic and environmental changes (SWSD, 2015; Wikipedia, 2020), Summer and winter seasons in Sulaimani are illustrated in Figure 2 below.

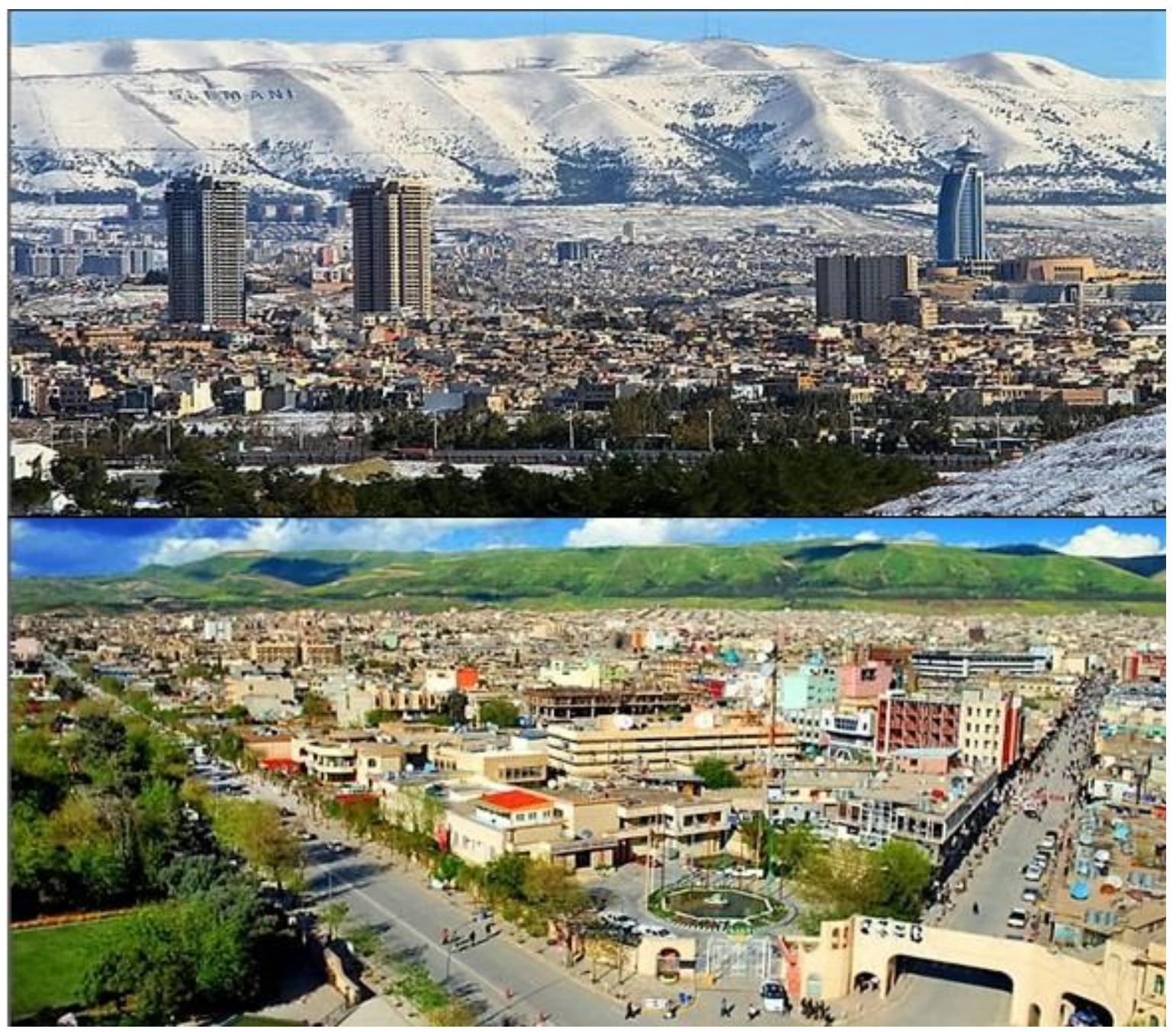

Figure 2. Summer (upper) and winter (lower) seasons in Sulaimani.

According to RIMP (2015) the population was 1.93 million with annual growth rates of $3 \%$ in 2015. In 1987, $63 \%$ of its population lived in the urban centers while $37 \%$ lived in the country sides. In the year 2008, urban population increased to $78 \%$ while the rural population dropped to $22 \%$ and the rates of urbanization was $3 \%$. This indicates that a rapid rate of rural to urban conversion occurred in the last two decades,

\section{Input Data}

In the present study, the meteorological data of 7 synoptic stations over a 23 -year time period (1992-2015) were obtained in a quality controlled format from the Meteorological Organization of Sulaimani as illustrated in Table 1 below. The selected stations for this study 
have complete 23 years records, representing a good spatial distribution over elevation ranges in Sulaimani as shown in Figure 3 below.

Table 1. Location and elevation of weather stations in Sulaimani province.

\begin{tabular}{c|cccc}
\hline Weather Stations & Latitude & Longitude & Altitude (m) & Years \\
\hline Sulaimani Centre & 35.33 & 45.27 & 884.8 & $1992-2015$ \\
Chamchamal & 35.52 & 44.82 & 725 & $2000-2015$ \\
Darbandikhan & 35.09 & 45.47 & 513 & $2002-2015$ \\
Bazyan & 35.36 & 45.08 & 830 & $2002-2015$ \\
Penjwin & 35.37 & 45.56 & 1302 & $2002-2015$ \\
Halabja & 35.11 & 45.98 & 695 & $2002-2015$ \\
Dukan & 35.94 & 44.96 & 539 & $2002-2015$ \\
\hline
\end{tabular}

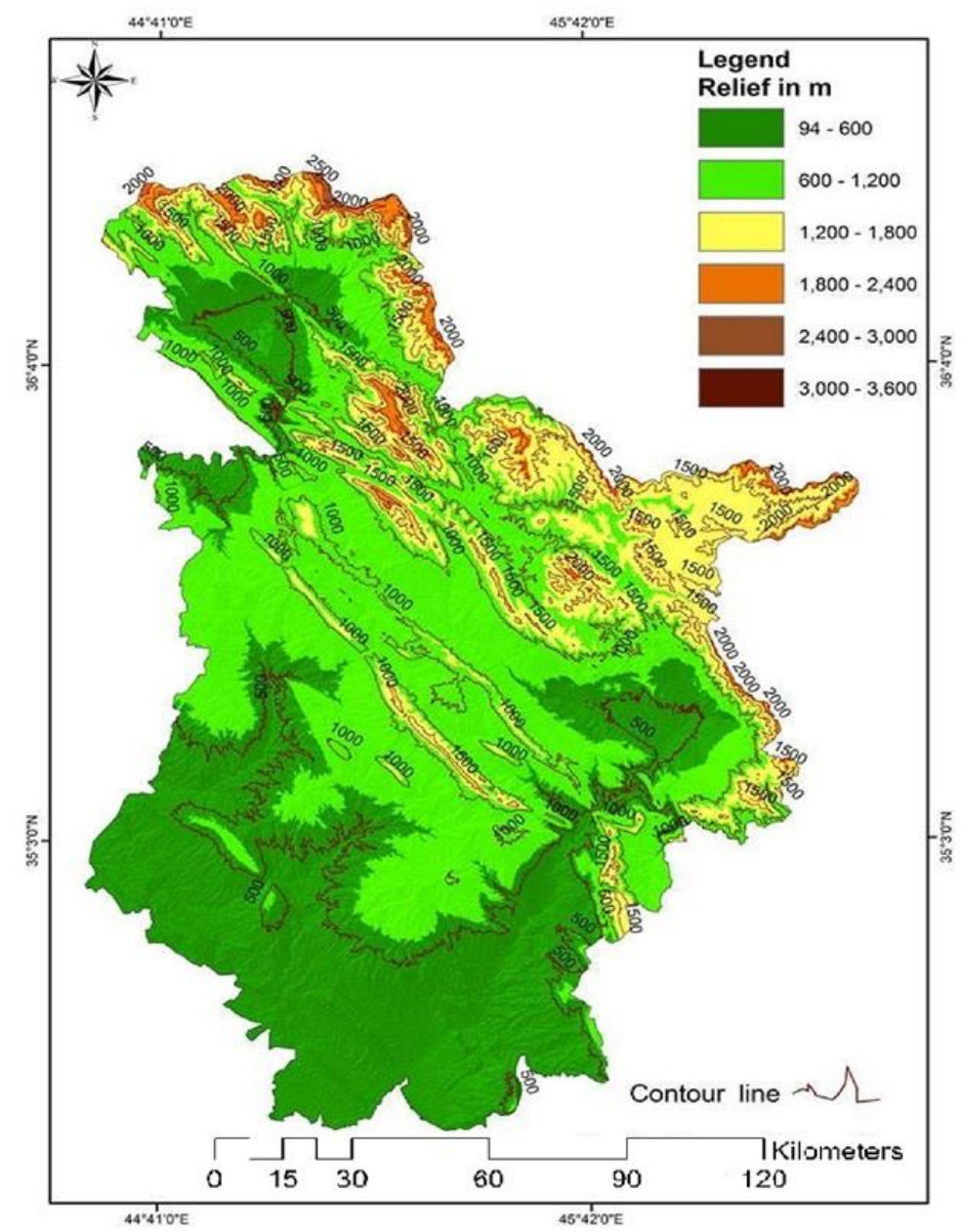

Figure 3. Elevation map of the study area 
The values of air temperature, relative humidity and wind speed were collected from each synoptic station to obtain the mean monthly values of Physiologically Equivalent Temperature (PET) in the Rayman Model.

\section{Rayman Model}

The Rayman model which developed according to Guideline 3787 of the German Association of Engineers (VDI 1998) calculates the radiation flux in simple and complex environments on the basis of various parameters (Matzarakis, et al. 2007). The final output of this model is the calculated mean radiant temperature, which is required in the energy balance model for humans. Consequently, it is also required for the assessment of bioclimatic comfort indices, such as Predicted Mean Vote (PMV), Physiologically Equivalent Temperature (PET), and Standard Effective Temperature (SET) as seen in Figures 4 and 5.

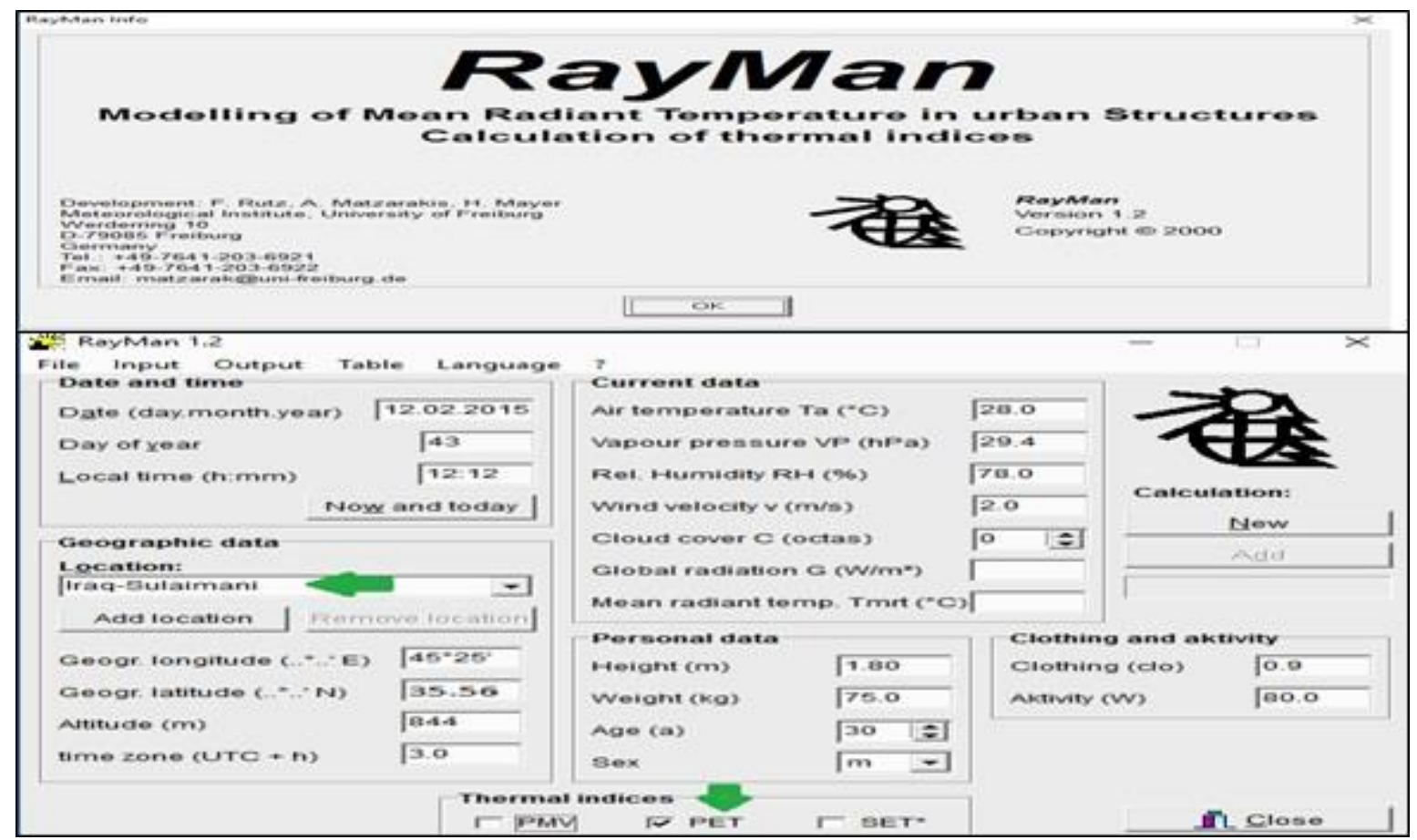

Figure 4. Graphical user interface of Rayman model 


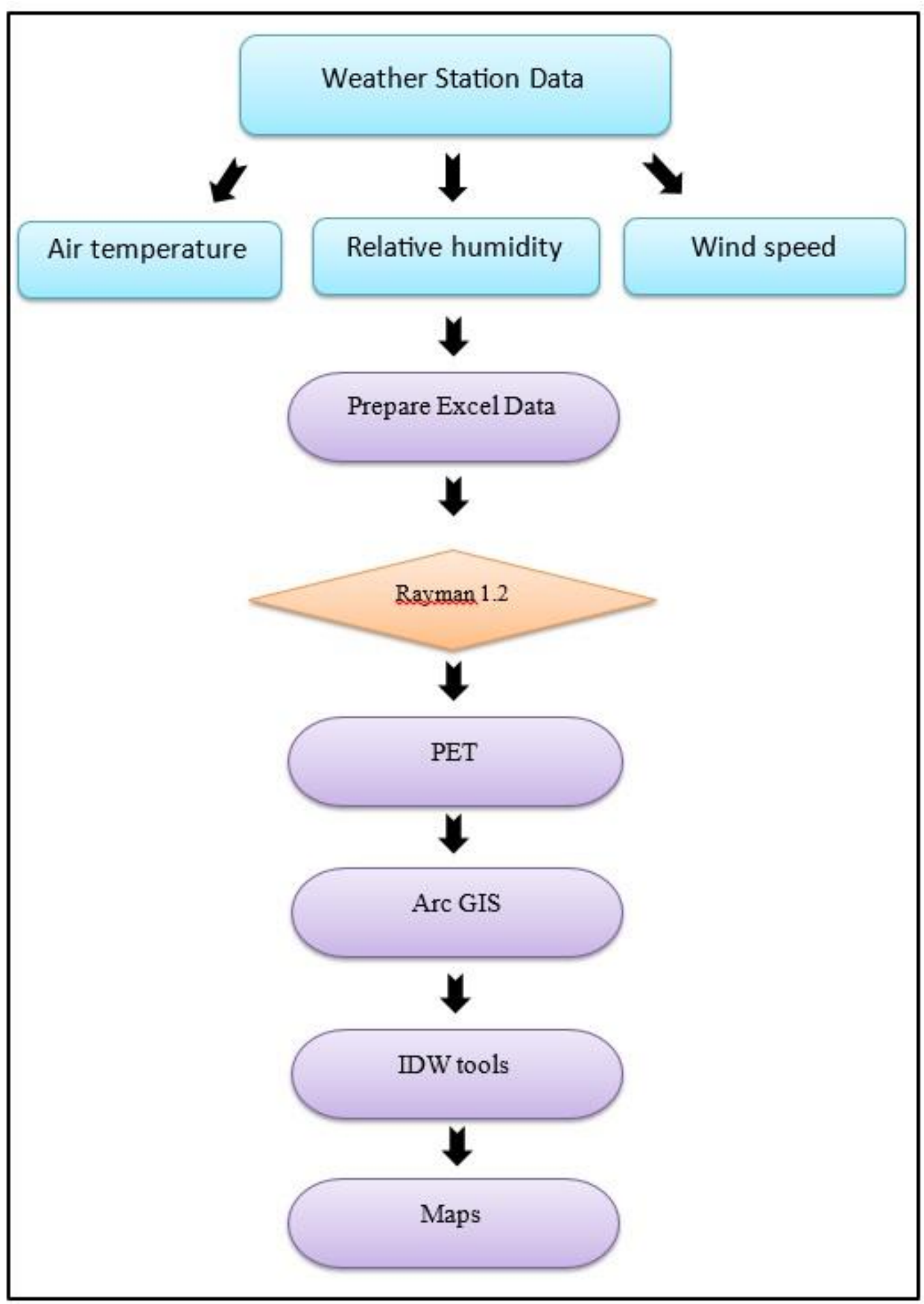

Figure 5. Flowchart of the study

PET is a thermal index that is used for the estimation of the thermal component for a given environment. The PET allows humans to predict their thermal perception of weather conditions. Therefore, analyzing thermal adaptation characteristics and comfort levels of residents from different regions is quite important to adequately describe the perception of these people (Lin and Matzarakis, 2008). PET can be employed for both indoor and outdoor environment which can be calculated with the bioclimatic model of Rayman. 
It is necessary to determine all meteorological variables that are important for the human energy balance to calculate PET. These variables include air temperature (Ta), vapour pressure (VP), relative humidity (RH), wind velocity (v), mean cloud cover (C) and mean radiant temperature (Tmrt). Human parameters influencing PET, such as activity, heat resistance of clothing, height, and weight are usually standardized in MEMI (Matzarakis, et al. 2010). In order to quantify the perception of the thermal environment by humans, threshold values for PET have been developed, which indicate different levels of thermal stress in the form of a graded index (Matzarakis and Mayer, 1996) as illustrated in Table 2. Threshold values of the PET for different thermal perceptions and levels of thermal stress, related to a metabolic rate of $80 \mathrm{~W}$ (walking) and a heat transfer resistance of clothing of 0.9 (summer clothing). The calculated PET values referred to a person who is $1.75 \mathrm{~m}, 75 \mathrm{~kg}$, and 35 years old standing male in the sun.

Table 2: Physiologically Equivalent Temperature (PET) for different grades of thermal sensation and physiological stress on human beings.

\begin{tabular}{l|ll}
\hline PET $\left({ }^{\circ} \mathrm{C}\right)$ & Thermal sensation & Physiological stress level \\
\hline$<4$ & very cold & extreme cold stress \\
$4-8$ & cold & strong cold stress \\
$8-13$ & cold & moderate cold stress \\
$13-18$ & slightly cool & slight cold stress \\
$18-23$ & comfortable & no thermal stress \\
$23-29$ & slightly warm & slight heat stress \\
$29-35$ & warm & moderate heat stress \\
$35-41$ & hot & strong heat stress \\
$>41$ & very hot & extreme heat stress \\
\hline
\end{tabular}

The values of air temperature, relative humidity, and wind speed were collected from each synoptic station as shown in Table 3, to obtain the mean monthly values of Physiologically Equivalent Temperature (PET) in the Rayman Model. 
Table 3. Mean monthly wind speed, humidity and temperatures values of all stations (19922015) in Sulaimani Province.

\begin{tabular}{|c|c|c|c|c|c|c|c|c|}
\hline \multicolumn{2}{|c|}{$\begin{array}{l}\text { Weather } \\
\text { Stations }\end{array}$} & Sulaimani & Dukan & Halabja & Chamchamal & Penjwin & Bazian & Darbandikhan \\
\hline \multirow[t]{3}{*}{ Jan } & $\mathrm{T}^{\mathrm{o}}$ & 10.5 & 13.1 & 16.7 & 11.9 & 8.6 & 14.6 & 16.2 \\
\hline & $\mathrm{H} \%$ & 69.7 & 66.3 & 59.6 & 66.8 & 75.9 & 65.3 & 57.9 \\
\hline & $\mathrm{W} \mathrm{s} / \mathrm{m}$ & 1.1 & 2.5 & 1.2 & 1.7 & 4.3 & 1.5 & 2.2 \\
\hline \multirow[t]{3}{*}{ Feb } & $\mathrm{T}^{\mathrm{o}}$ & 12.2 & 16 & 19.2 & 13.7 & 12.1 & 18.1 & 19.7 \\
\hline & $\mathrm{H} \%$ & 66.7 & 63.4 & 59.6 & 62.1 & 73.3 & 63.3 & 64.7 \\
\hline & $\mathrm{W} \mathrm{s} / \mathrm{m}$ & 1.4 & 2.6 & 1.6 & 1.8 & 3.5 & 1.3 & 2.4 \\
\hline \multirow[t]{3}{*}{ Mar } & $\mathrm{T}^{\mathrm{o}}$ & 17.2 & 22.3 & 25.8 & 18.8 & 19.4 & 23.6 & 26.3 \\
\hline & $\mathrm{H} \%$ & 57 & 59.2 & 51.2 & 50.4 & 65.3 & 59.6 & 59.5 \\
\hline & $\mathrm{W} \mathrm{s} / \mathrm{m}$ & 1.6 & 3.1 & 1.9 & 1.8 & 3.5 & 1.5 & 2.6 \\
\hline \multirow[t]{3}{*}{ Apr } & $\mathrm{T}^{\mathrm{o}}$ & 22.6 & 27.6 & 30.8 & 24.1 & 23.5 & 28.1 & 32.6 \\
\hline & $\mathrm{H} \%$ & 53.8 & 56.7 & 50.3 & 46.9 & 64.4 & 60.3 & 51.8 \\
\hline & $\mathrm{W} \mathrm{s} / \mathrm{m}$ & 1.4 & 2.8 & 1.8 & 1.5 & 4.7 & 1.5 & 2.3 \\
\hline \multirow[t]{3}{*}{ May } & $\mathrm{T}^{\mathrm{o}}$ & 29.3 & 35 & 38.6 & 29.8 & 30.7 & 35.7 & 39.3 \\
\hline & $\mathrm{H} \%$ & 42.8 & 42.5 & 37.9 & 33.7 & 57.7 & 50.7 & 46.6 \\
\hline & $\mathrm{W} \mathrm{s} / \mathrm{m}$ & 1.5 & 2.6 & 2.1 & 1.9 & 4 & 1.1 & 2.2 \\
\hline \multirow[t]{3}{*}{ Jun } & $\mathrm{T}^{\mathrm{o}}$ & 35.7 & 39.9 & 43.6 & 37.3 & 35.9 & 40.6 & 43.8 \\
\hline & $\mathrm{H} \%$ & 27.7 & 27 & 22.9 & 21.9 & 49.1 & 33.7 & 25.2 \\
\hline & $\mathrm{W} \mathrm{s} / \mathrm{m}$ & 1.9 & 3.2 & 2.2 & 2.2 & 4 & 1.6 & 2.2 \\
\hline \multirow[t]{3}{*}{ Jul } & $\mathrm{T}^{\mathrm{o}}$ & 39.6 & 44.4 & 46.1 & 40.7 & 38.6 & 42.6 & 46 \\
\hline & $\mathrm{H} \%$ & 25.6 & 24.1 & 27.8 & 20.6 & 42.6 & 30.5 & 32.5 \\
\hline & $\mathrm{W} \mathrm{s} / \mathrm{m}$ & 1.7 & 2.9 & 2.2 & 2 & 3.4 & 1.7 & 2.2 \\
\hline \multirow[t]{3}{*}{ Aug } & $\mathrm{T}^{\mathrm{o}}$ & 39.5 & 43.8 & 46 & 40.5 & 38.4 & 42.8 & 45.7 \\
\hline & $\mathrm{H} \%$ & 24 & 24.3 & 29 & 21.6 & 37 & 28.8 & 23.3 \\
\hline & $\mathrm{W} \mathrm{s} / \mathrm{m}$ & 1.4 & 2.5 & 2.1 & 2.2 & 3.8 & 1.5 & 2 \\
\hline \multirow[t]{3}{*}{ Sep } & $\mathrm{T}^{\mathrm{o}}$ & 34.7 & 40.2 & 42.5 & 36 & 34.9 & 39.9 & 42 \\
\hline & $\mathrm{H} \%$ & 28.5 & 26.7 & 34.2 & 26 & 46 & 32.5 & 25.1 \\
\hline & $\mathrm{W} \mathrm{s} / \mathrm{m}$ & 1.5 & 2.2 & 2 & 1.9 & 3.8 & 1.1 & 1.8 \\
\hline \multirow[t]{3}{*}{ Oct } & $\mathrm{T}^{\mathrm{o}}$ & 28.2 & 33.5 & 36.3 & 30.1 & 28.6 & 33.7 & 35.3 \\
\hline & $\mathrm{H} \%$ & 43.6 & 39.3 & 31.4 & 35.3 & 56.8 & 42.9 & 35.1 \\
\hline & $\mathrm{W} \mathrm{s} / \mathrm{m}$ & 1.5 & 2.2 & 1.7 & 1.9 & 3.1 & 1.1 & 2 \\
\hline \multirow[t]{3}{*}{ Nov } & $\mathrm{T}^{\mathrm{o}}$ & 18.6 & 22.2 & 25.3 & 20.4 & 18.6 & 24.3 & 28 \\
\hline & $\mathrm{H} \%$ & 58.5 & 60.6 & 47.3 & 48 & 68.7 & 59 & 54.3 \\
\hline & $\mathrm{W} \mathrm{s} / \mathrm{m}$ & 1.1 & 2.2 & 1.3 & 1.8 & 2.9 & 1.2 & 2.1 \\
\hline \multirow[t]{3}{*}{ Dec } & $\mathrm{T}^{\mathrm{o}}$ & 13.2 & 16 & 19.6 & 14.5 & 14.1 & 18.3 & 19.5 \\
\hline & $\mathrm{H} \%$ & 64.2 & 64 & 56.2 & 53.8 & 66.7 & 59.5 & 62.2 \\
\hline & $\mathrm{W} \mathrm{s} / \mathrm{m}$ & 1 & 2.3 & 1.4 & 1.7 & 2.1 & 1.1 & 2.2 \\
\hline
\end{tabular}




\section{RESULTS AND DISCUSSION}

Monthly PET values were calculated using Rayman model with the inputs of the mean monthly values of air temperature, relative humidity, and wind speed for each station as illustrated in Figure 6 below as the PET values were color coded to reflect the thermal stress by months and weather station. The PET values were also mapped using the values in Table 4 with the inverse distance weighted (IDW) method, generally used as a simple local interpolation technique in ArcGIS (Lo and Yeung, 2002). As a result, the final mean monthly PET maps are illustrated in Figures 7, 8,9, and 10 for the study area. The same map legend is used to allow for a better comparison of the months.

\begin{tabular}{|c|c|c|c|c|c|c|c|c|c|c|c|c|}
\hline & Jan & Feb & Mar & Apr & May & Jun & Jul & Aug & Sep & Oct & Nov & Dec \\
\hline Sulaimani & 11.3 & 14.9 & 21.7 & 30.7 & 39.2 & 46.7 & 519 & 51.9 & 44.3 & 34.0 & 20.7 & 14.2 \\
\hline Dokan & 11.6 & 16.1 & 24.6 & 34.1 & 44.6 & 50.8 & 570 & 56.3 & 50.4 & 39.6 & 22.8 & 14.4 \\
\hline Darbandinkhan & 15.4 & 20.7 & 31.2 & 41.6 & 50.8 & 57.4 & 59.6 & 58.9 & 53.1 & 42.1 & 30.4 & 18.7 \\
\hline Bazian & 14.8 & 21.3 & 30.0 & 37.5 & 48.2 & 53.7 & 559 & 55.6 & 51.3 & 415 & 27.5 & 19.4 \\
\hline Halabja & 18.0 & 21.7 & 31.5 & 39.9 & 49.6 & 56.5 & 59.2 & 58.6 & 53.1 & 43.5 & 28.3 & 20.1 \\
\hline Chamchamal & 13.7 & 16.9 & 25.5 & 34.6 & 41.1 & 50.3 & 54.4 & 53.0 & 46.4 & 37.1 & 23.3 & 15.2 \\
\hline Penjwen & 4.8 & 10.4 & 20.0 & 25.0 & 36.8 & 44.9 & 487 & 47.8 & 41.2 & 32.0 & 18.1 & 12.6 \\
\hline$>41$ & \multicolumn{4}{|c|}{ very hot } & & & & & & & & \\
\hline $35-41$ & \multicolumn{4}{|c|}{ Hot } & & & & & & & & \\
\hline $29-35$ & \multicolumn{4}{|c|}{ Warm } & & & & & & & & \\
\hline $23-29$ & \multicolumn{4}{|c|}{ slightly warm } & & & & & & & & \\
\hline $18-23$ & \multicolumn{4}{|c|}{ comfortable } & & & & & & & & \\
\hline $13-18$ & \multicolumn{4}{|c|}{ slightly cool } & & & & & & & & \\
\hline $8-13$ & \multicolumn{4}{|c|}{ Cold } & & & & & & & & \\
\hline $4-8$ & \multicolumn{4}{|c|}{ Cold } & & & & & & & & \\
\hline$<4$ & \multicolumn{4}{|c|}{ very cold } & & & & & & & & \\
\hline
\end{tabular}

Figure 6. The PET classification by color for all months in Sulaimani.

According to the results, the PET values ranged from $4.8^{\circ} \mathrm{C}$ to $59.6^{\circ} \mathrm{C}$ in Sulaimani for the period of 1992 to 2015. During the winter months, the coldest PET value were observed in the northeast of the Province (Penjwin) in December with $4.8{ }^{\circ} \mathrm{C}$ as illustrated in Figure 6 and 7. During December, the hottest PET values were calculated at Halabja, Bazian, and Darbandiukhan. 


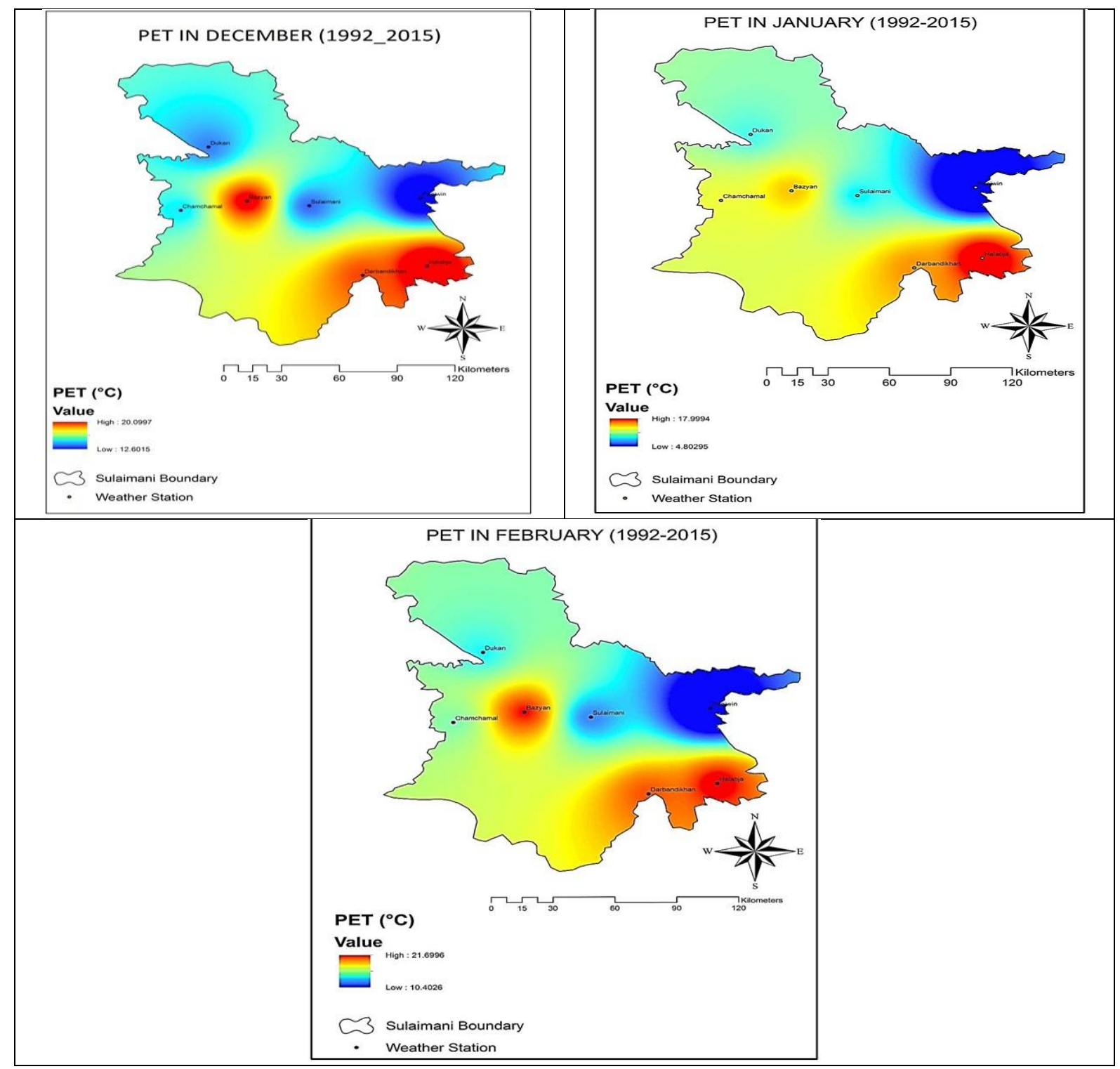

Figure 7. PET maps of winter in Sulaimani. December (upper left), January (upper right), and February (bottom) 


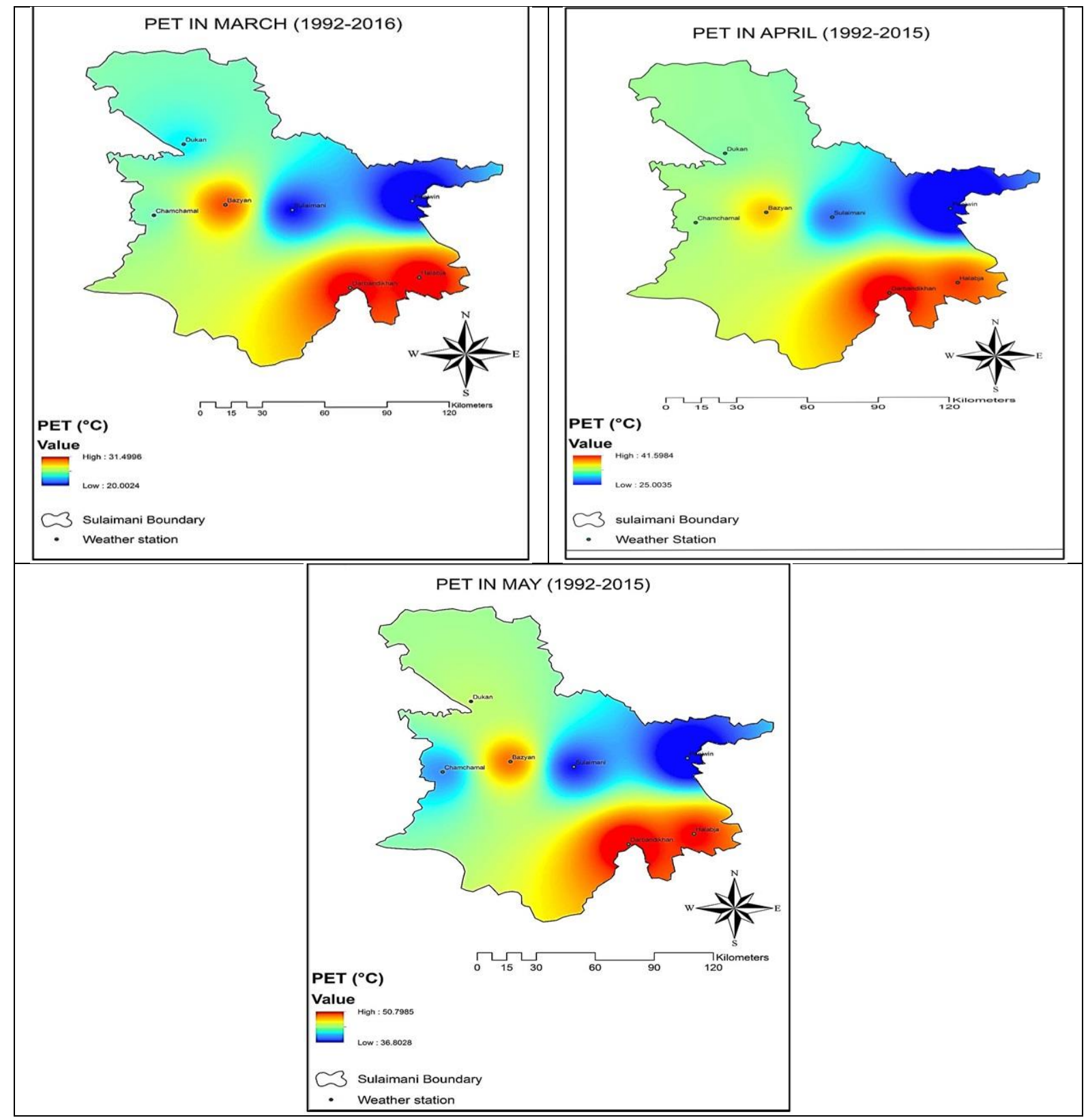

Figure 8. PET maps of spring in Sulaimani. March (upper left), April (upper right), and May (bottom).

In the spring months, the lowest PET values were obtained in March and highest values were seen in May as illustrated in Figure 6 and Figure 8. 


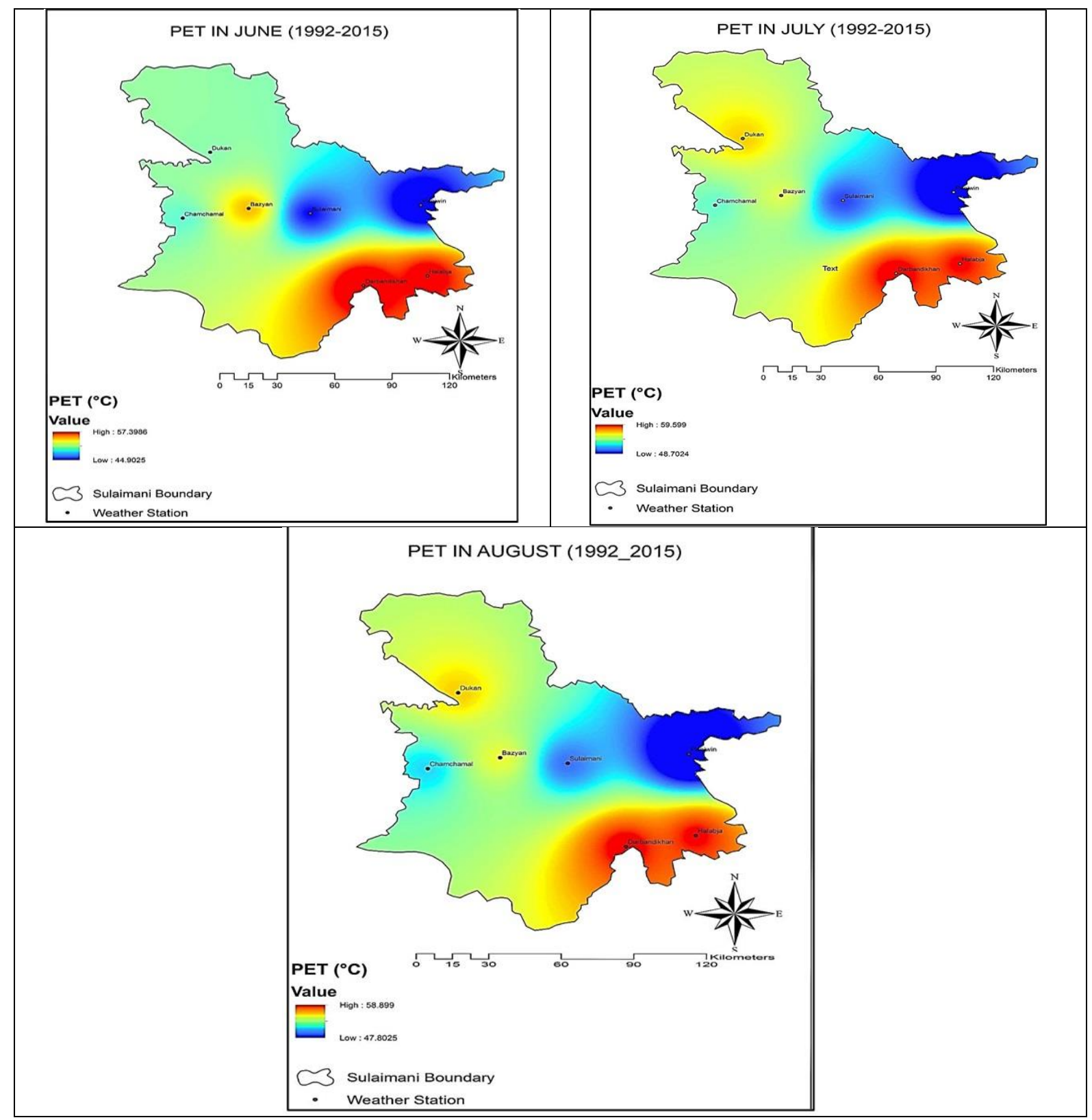

Figure 9. PET maps of summer in Sulaimani. June (upper left), July (upper right), and August (bottom).

Summer months illustrated highest PET values in Sulaimani as seen in Figure 9 above. In fall, lowest PET was seen in November in Penjwen, Dokan and Sulaimani. PET values in September were as high as in summer months as shown in Figure 6 and 10. 


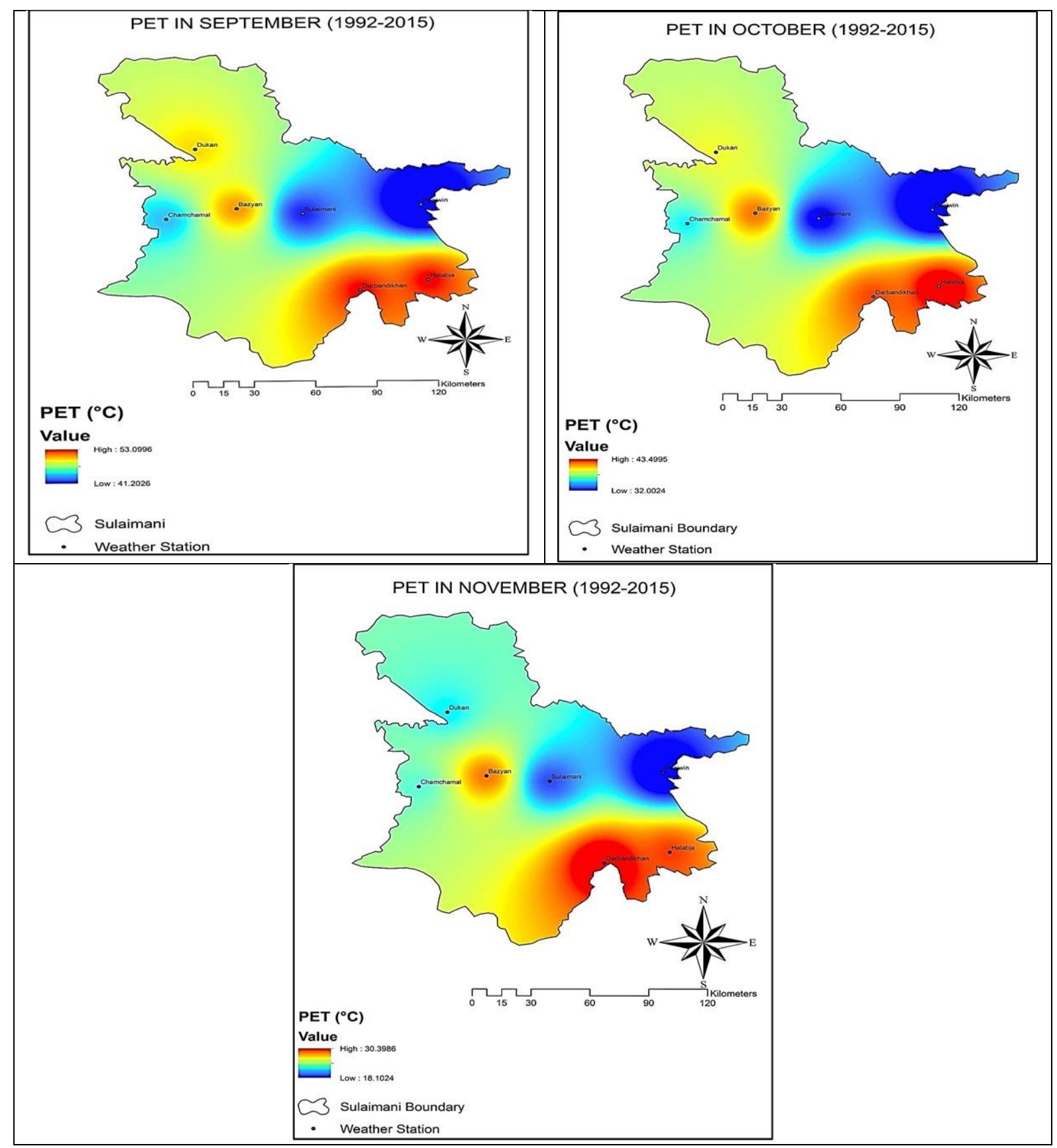

Figure 10. PET maps of autumn in Sulaimani. September (upper left), October (upper right), and November (bottom)

The final PET values ranged from $4.8^{\circ} \mathrm{C}$ to $59.6{ }^{\circ} \mathrm{C}$ in Sulaimani. The coldest PET values were observed in Penjwen area during the month of December with $4.8^{\circ} \mathrm{C}$ while the highest PET values were observed in Darbandiukhan during the month of July with $59.6{ }^{\circ} \mathrm{C}$.

\section{CONCLUSIONS}

The PET is a popular method for the assessment of thermal comfort and thermal stress used by decision makers. The monthly PET values observed in Sulaimani ranged from $4.8{ }^{\circ} \mathrm{C}$ to 59.6 ${ }^{\circ} \mathrm{C}$ using Rayman model. The coldest PET values were observed in Penjwen region while the 
hottest PET values were found in Darbandiukhan region during the summer months. We can conclude that topography is the main reason for the differences in the PET. Urban expansion and urban sprawl are the second reason for PET differences. Water surfaces and green areas can be effective in cooling the city.

In Sulaimani, February, March, November and December were found to be the best suitable months for outdoor activity during the year. January is the coldest month while May through September are the hottest months in Sulaimani. We hope that city officials take these results into account for outdoor recreation planning.

\section{AUTHOR CONTRIBUTIONS}

Shakhwan Hama Shareef: Organizing weather data, creating maps, help in manuscript writing. Hakan Oguz: Analyzing weather data using Rayman model and ArcGIS, writing, editing and reviewing the manuscript.

\section{ACKNOWLEDGEMENTS}

The authors would like to thank the Ministry of Agriculture and Water Resources of Iraq for providing the meteorological data.

\section{REFERENCES}

Daneshvar, M. R. M., Bagherzadeh, A., \& Tavousi, T. (2013) Assessment of bioclimatic comfort conditions based on Physiologically Equivalent Temperature (PET) using the RayMan Model in Iran, Central European Journal of Geosciences, 5(1), 53-60.

Farajzadeh H., \& Matzarakis A. (2012) Evaluation of thermal comfort conditions in Ourmieh Lake, Iran. Theoretical and Applied Climatology, 107, 451-459.

Hamad, T. A., \& Oguz, H. (2020) Determining thermal comfort zones for outdoor recreation planning: A case study of Erbil-Iraq, Turkish Journal of Forest Science, 4(1). 133-145.

Hoppe, P. R. (1999) The physiological equivalent temperature - a universal index for the biometeorological assessment of the thermal environment. International Journal of Biometeorology, 43, 71-75.

Knes, I. \& Thorsson, S. (2006) Influences of culture and environmental attitude on thermal, emotional and perceptual evaluations of a public square. International Journal of Biometeorology, 50:258-268.

Lin, T. P. \& Matzarakis, A. (2008) Tourism climate and thermal comfort in Sun Moon Lake, Taiwan. International Journal of Biometeorology, 52, 281-290.

Lin, T. P. \& Matzarakis, A. (2011) Tourism-climate information based on human thermal perception in Eastern China and Taiwan. Tourism Management, 32, 492-500.

Lo, C. P. \& Yeung, A. K.W. (2002) Concepts of Techniques of GIS. Prentice Hall, New Jersey.

Matallah, M. E., Alkama, D., Ahriz, A., \& Attia, S. (2020) Assessment of the Outdoor Thermal Comfort in Oases Settlements, Atmosphere, 11(2), 185, 1-17

Matzarakis, A., Mayer, H. \& Iziomon, M. G. (1999) Applications of a universal thermal index: physiological equivalent temperature. International Journal of Biometeorology, 43, 7684 . 
Matzarakis, A. (2006) Weather and climate related information for tourism. Tourism and Hospitality Planning \& Development, 3, 99-115.

Matzarakis, A., Rutz, F. \& Mayer, H. (2010) Modelling Radiation fluxes in simple and complex environments - Basics of the Rayman model. International Journal of Biometeorology, 54, 131-139.

Matzarakis, A., Rutz, F. \& Mayer, H. (2007) Modelling Radiation fluxes in easy and complex environments - Application of the Rayman model. International Journal of Biometeorology, 51, 323-334.

Matzarakis, A. \& Mayer, H. (1996) Another kind of environmental stress: Thermal stress. WHO collaborating centre for Air Quality Management and Air pollution Control. Newsletters, 18, 7-10.

Mieczkowski, Z. (1985) The tourism climate index: a method for evaluating world climates for tourism. Canadian Geographer, 29, 220-233.

Morgan, R., Gatell, E., Junyent, R., Micallef, A., Özhan, E. \& Williams, A. (2000) An improved user - based beach climate index. Journal of Coastal Conservation, 6, 41-50.

Nikolopoulou, M. \& Steemers, K. (2003) Thermal comfort and psychological adaptation as a guide for designing urban spaces. Energy and Buildings, 35:95-101.

RIMP (2015) Republic of Iraq Ministry of Planning. Retrieved from: https://mop.gov.iq/en/

Stathopoulos, T., Wu, H., \& Zacharias, J. (2004) Outdoor human comfort in an urban climate. Building and Environment, 39:297-305.

SWSD (2015) Sulaimani Weather Station Data. Retrieved from the office in Sulaimani-Iraq.

Topay, M. (2013) Mapping of thermal comfort for outdoor recreation planning using GIS: the case of Isparta Province (Turkey) Turkish Journal of Agriculture and Forestry, 37: 110120.

Toy, S., Y1lmaz, S., \& Y1lmaz, H. (2005) Determination of bioclimatic comfort in three different land uses in the city of Erzurum, Turkey. Building and Environment, 42: 13151318.

VDI. (1998) Methods for the human biometeorological evaluation of climate and air quality for the urban and regional planning. Part I: Climate. Beuth, Berlin, VDI guideline 3787, Part 2.

Wikipedia (2015) Sulaimani Province. Retrieve from: https://en.wikipedia.org/wiki/Sulaymaniyah

Y1lmaz, S., Akif, I. M. \& Matzarakis, A. (2013) Global NEST Journal, 15(3), 408-420.

Zengin, M., Kopar, İ., \& Karahan, F. (2010) Determination of bioclimatic comfort in ErzurumRize expressway using GIS. Building and Environment, 5, 158-164. 